\title{
EFEKTIFITAS SISTEM PEMBELAJARAN DARING SEBAGAI DAMPAK PANDEMI COVID-19 DI STIKES Dirgahayu Samarinda
}

\author{
Vinsensia Tetty ${ }^{1}$, Bonifasius Hat ${ }^{2}$ \\ Stikes Dirgahayu Samarinda ${ }^{1}$, Stikes Dirgahayu Samarinda ${ }^{2}$ \\ (Jl. Pasundan No. 21, telp 0541-748335) \\ e-mail: tetty.vinsen@gmail.com
}

\begin{abstract}
ABSTRAK
Pembelajaran secara daring dianggap menjadi solusi kegiatan belajar mengajar tetap jalan di tengah pandemi corona. Setiap kampus memiliki kebijakan masing-masing dalam menyikapi aturan ini. Beberapa kampus merombak jadwal mata kuliah yang akan diberikan kepada mahasiswa setiap harinya. Mata kuliah yang diberikan dalam satu hari hanya tiga jenis, ditambah dengan lembar kegiatan yang harus diselesaikan mahasiswa setiap hari. Beberapa kampus memberikan kebijakan agar mahasiswa nggak hanya belajar materi pelajaran. Tetapi juga mengasah soff skill dengan membantu kegiatan di rumah. Mengetahui efektifitas sistem pembelajaran daring sebagai dampak Pandemi Covid-19 bagi mahasiswa di STIKES Dirgahayu Samarinda merupakan tujuan penelitian ini dengan menggunakan desain penelitian deskriptif kuantitatif dengan menggunakan metode survey yang dilakukan secara online. Pengambilan sampel menggunakan tehnik total sampling yaitu seluruh mahasiswa STIKES Dirgahayu Samarinda. Pengumpulan data diperoleh menggunakan kuesioner yang dibuat dalam Format google dokumen yang diberikan kepada mahasiswa secara online melalui grup WhatsApp.. Hasil penelitian adalah sebagian besar mahasiswa mengatakan mereka menggunakan jaringan internet jenis paket data dan menggunakan handphone untuk mengikuti perkulihan secara daring, sedangkan untuk aplikasi yang digunakan terbanyak adalah google class room, zoom dan whatsapp. Aplikasi pembelajaran, pada umumnya pada tingkat baik atau puas dan sedang, aspek Tangibles, sebagian besar berpendapat bahwa dosen siap namun masih terdapat beberapa dosen yang dinilai kurang siap oleh mahasiswa.Aspek Reliability, tingkat kepuasan mahasiswa terhadap pelayanan yang diberikan oleh dosen sebagian besar mahasiswa berpendapat memuaskan, aspek Assurance, tingkat kepuasan mahasiswa terhadap perlakuan dosen selama proses pembelajaran daring sebagian besar menjawab memuaskan dan sangat memuaskan, aspek emphaty,tingkat kepuasan mahasiswa terhadap pemahaman dosen kepada mahasiswa pada umumnya menjawab memuaskan.
\end{abstract}

Kata kunci: Efektifitas, Covid-19, pembelajaran daring, STIKES Dirgahayu Samarinda

\section{PENDAHULUAN}

Pandemi Covid-19 telah membuat sistem pembelajaran di semua kampus terpaksa berubah secara drastis dari pertemuan tatap muka menjadi sistem pembelajaran secara daring. Banyak kampus yang belum memiliki infrastruktur pembelajaran daring namun diwajibkan melakukan perkuliahan secara daring. Penelitian ini bertujuan untuk menganalisis efektivitas sistem pembelajaran daring sebagai dampak Pandemi Covid-19. Penelitian ini menggunakan metode survey dengan kuesioner yang dilakukan secara online. STIKES Dirgahayu Samarinda mendukung kebijakan belajar dari rumah dengan memberlakukan pembelajaran daring menggunakan aplikasi Zoom 
untuk tatap muka, WhatsApp dan googleclassroom untuk memberikan materi kuliah serta penugasan untuk media belajar daring. Metode ini diterapkan untuk semua mata kuliah teori dan beberapa mata kuliah praktikum yang dengan pertimbangan tertentu dapat dilaksanakna secara daring.

Pembelajaran secara daring dianggap menjadi solusi kegiatan belajar mengajar tetap jalan di tengah pandemi corona. Meski cara ini menuai kontroversi. Bagi tenaga pengajar, sistem pembelajaran daring hanya efektif untuk penugasan. Mereka menganggap untuk membuat mahasiswa memahami materi, cara daring dinilai sulit. Selain itu, kemampuan teknologi dan ekonomi setiap siswa berbeda-beda, tidak semua mahasiswa memiliki fasilitas yang menunjang kegiatan belajar jarak jauh ini. Koneksi internet, fasilitas laptop atau handphone yang memadai, dan kuota internet yang mahal menjadi hambatan nyata.

Meskipun begitu kegiatan pembelajaran harus terus berlanjut sehingga setiap kampus memiliki kebijakan masing-masing dalam menyikapi aturan ini. Beberapa kampus merombak jadwal mata kuliah yang akan diberikan kepada mahasiswa, termasuk STIKES Dirgahayu Samarinda melakukan perubahan dengan merubah penempatan beberapa mata kuliah pada semester genap dan ganjil dengan maksud di masa pandemi ini lebih banyak mata kuliah teori yang dilaksanakan. Perubahan yang terjadi pada sistem pembelajaran inilah yang melatarbelakangi peneliti untuk melakukan penelitian dengan judul efektifitas sistem pembelajaran daring sebagai dampak pandemi Covid-19 pada mahasiswa STIKES Dirgahayu Samarinda.

\section{METODE PENELITIAN Rancangan Penelitian}

\begin{abstract}
Rancangan penelitian ini akan menggunakan desain penelitian deskriptif (cross sectional). Pengambilan sampel menggunakan tehnik total Sampling yaitu pengambilan sampel adalah seluruh mahasiswa STIKES Dirgahayu Samarinda. Pengumpulan data diperoleh menggunakan lembar kuesioner yang dibuat dalam google format dan dibagikan kepada seluruh mahasiswa secara online melalui grup WhatsApp.
\end{abstract}

\section{HASIL}

Tabel 4.1 Data responden berdasarkan asal program studi

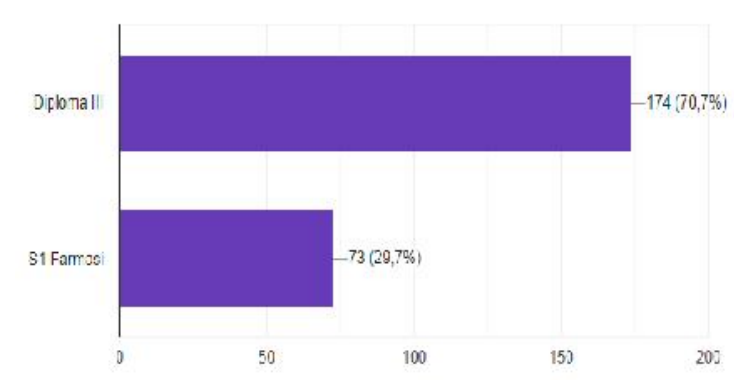

Berdasarkan tabel 4.1 data responden berdasarkan asal program studi, diperoleh bahwa 70,7 \% responden adalah mahasiswa program studi D3 keperawatan dan 29,7 \% responden adalah mahasiswa prodi S1 Farmasi.

Tabel 4.2 Data responden berdasarkan tahun mulai kuliah

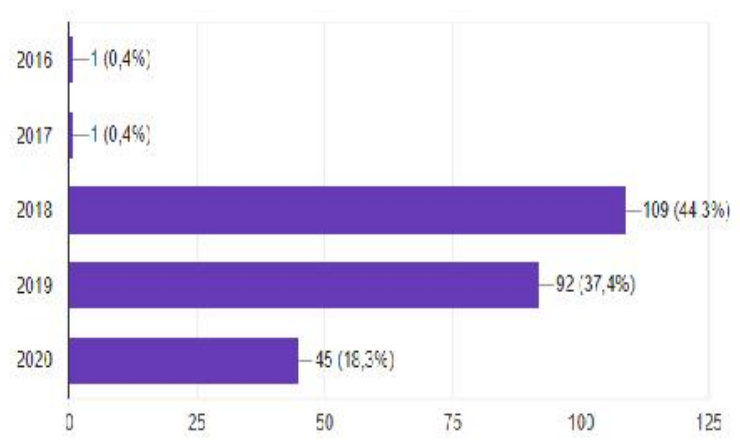

Berdasarkan tabel 4.2 diperoleh bahwa tahun mulai kuliah yang terbanyak yaitu yang masuk tahun 2018 yaitu sebesar $44,3 \%$.

Tabel 4.3 Data responden berdasarkan usia 


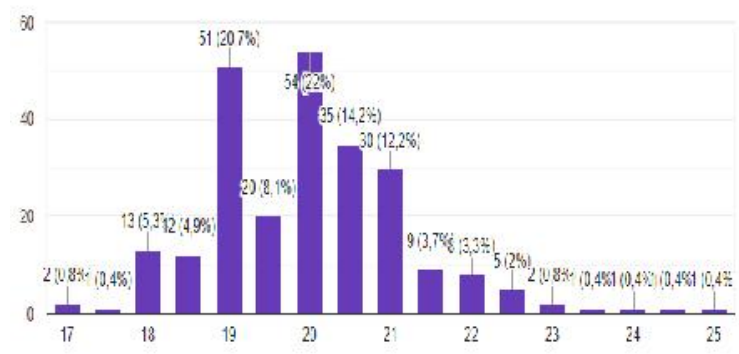

Berdasarkan tabel 4.3, terlihat bahwa usia terbanyak responden yaitu 20 tahun sebesar 22 54 orang.

Tabel 4.4 Data responden berdasarkan jenis kelamin

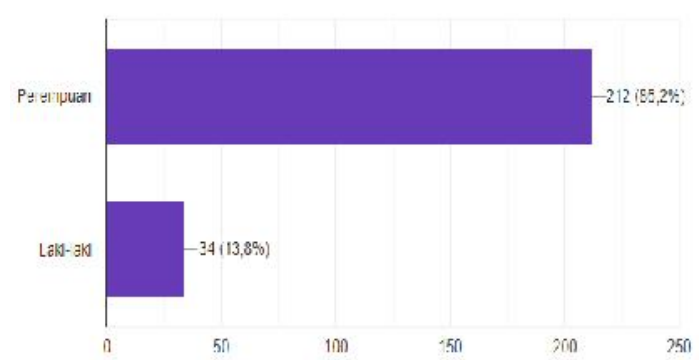

Berdasarkan tabel 4.4 didapatkan bahwa jenis kelamin responden terbanyak adalah perempuan yaitu sebesar $86,2 \%$.

\section{Tabel 4.5 Data Tempat Tinggal}

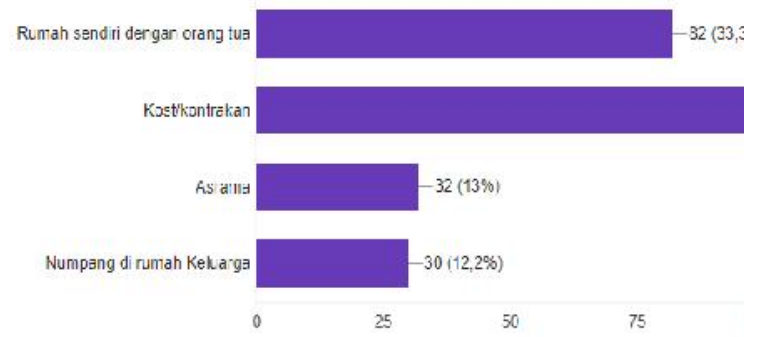

Berdasarkan tabel 4.5 didapatkan bahwa data 1 tinggal responden terbanyak adalah di kost/kon yaitu sebesar $43,1 \%$.

Tabel 4.6 Data posisi tinggal saudara saat ini

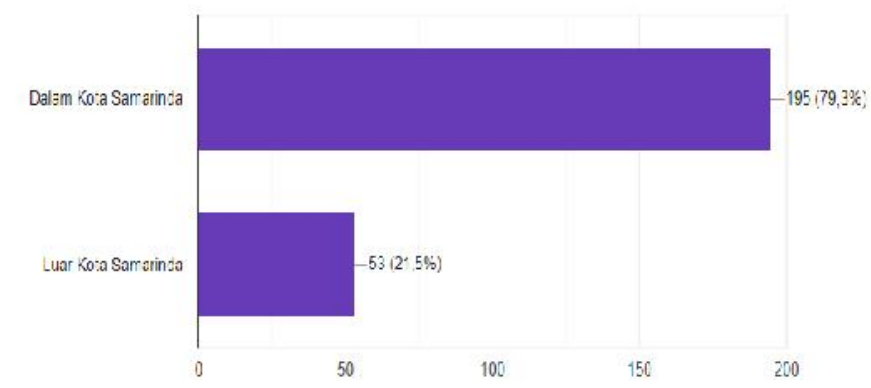

Bendausarkan tabel 4.6 terlihat bahwa sebagian besar responden saat ini tinggal dalam kota Samarinda yaitu sebesar 79,3 $\%$.

Tabel 4.7 Data sumber biaya kuliah

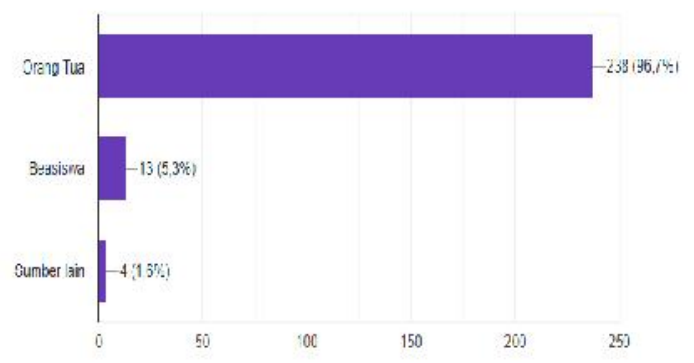

Berdasarkan tabel 4.7 sumber biaya kuliah terbanyak adalah orang tua yaitu sebesar $96,7 \%$.

Tabel 4.8 Fasilitas yang dimiliki untuk mengikuti kuliah

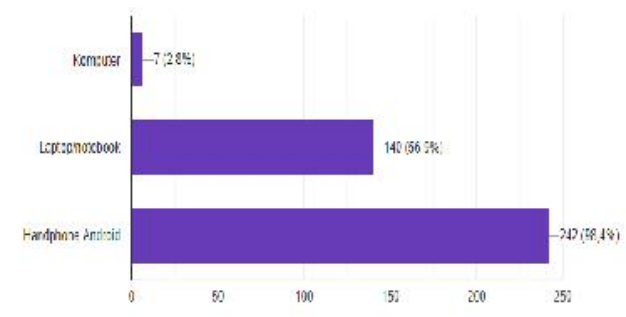

Berdasarkan tabel 4.8 fasilitas terbanyak yang dimiliki mahasiswa untuk mengikuti kuliah adalah Handphone android yaitu sebesar 98,4\%. 
Tabel 4.9 Aplikasi yang digunakan saat kuliah daring

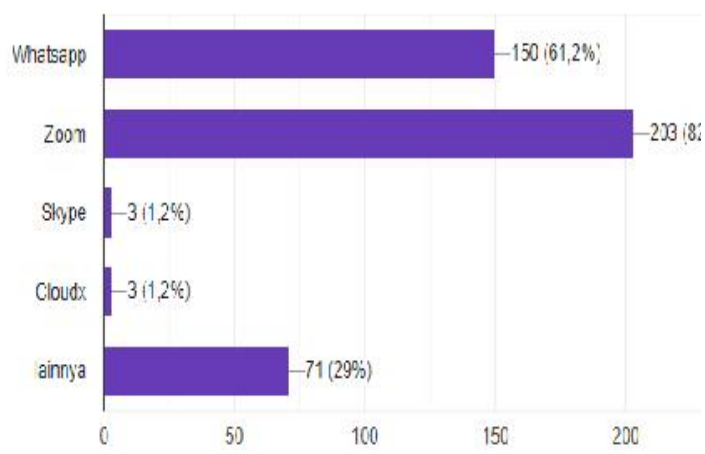

Berdasarkan tabel 4.9 aplikasi terbanyak yang digunakan responden saat mengikuti kuliah daring adalah Zoom sebesar $82,9 \%$ dan Whatsapp sebesar $61,2 \%$.

Tabel 4.10 Koneksi internet selama perkuliahan

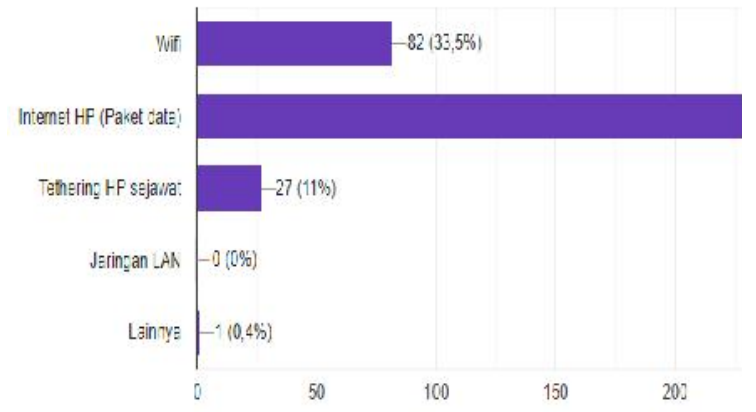

Berdasarkan tabel 4.10 koneksi internet yang banyak digunakan selama perkuliahan adalah paket data yaitu sebesar 93,5\%.

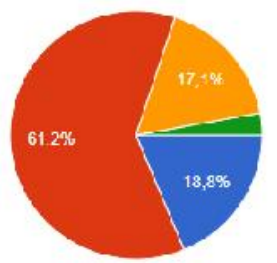

- SintLal sient - Siap - Kurang 3 ap - Sançat Kưang sla Gambar 4.11 Data kesiapan responden mengikutternet kuliah daring

Berdasarkan gambar 4.11 terlihat bahwa sebagerdasarkan gambar 4.14 disimpulkan

Berdasarkan gambar 4.11 terlihat bahwa sebagian ${ }^{2}$ hwa sebagian besar mahasiswa yaitu
besar responden mengatakan siap mengikutha kuliah daring dan sangat siap sebesar 18,8\%.

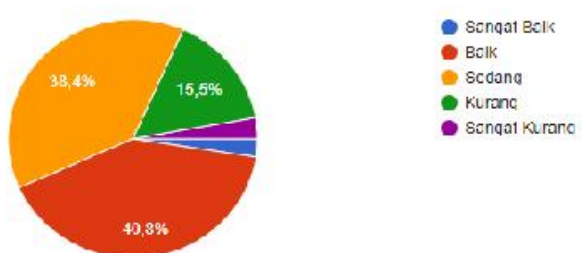

Gambar 4.12 Data seberapa baik responden memahami materi melalui kuliah daring

Berdasarkan gambar 4.12 sebagian responden mengatakan tingkat pemahaman terhadap materi yang disampaikan secara daring adalah baik yaitu $40,8 \%$ dan masih ada $15,5 \%$ yang merasa tingkat pemahamannya kurang.

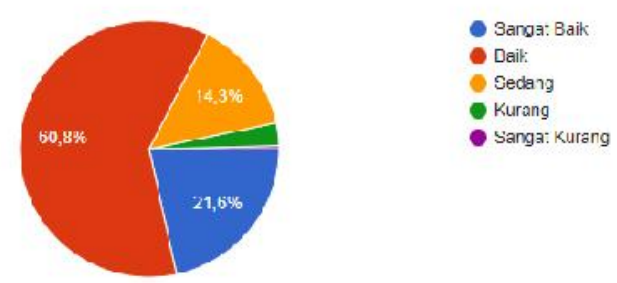

Gambar 4.13 Seberapa baik dosen menyampaikan materi saat kuliah daring

Berdasarkan gambar 4.13 terlihat bahwa sebagian besar respoden yaitu $60,8 \%$ berpendapat bahwa dosen menyampaikan materi saat kuliah daring baik dan 21,6\% mengatakan sangat baik
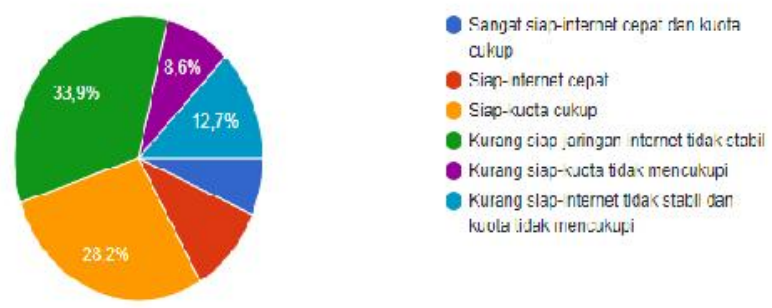

Gambar 4.14 Data kesiapan fasilitas mahasiswa mengikuti kuliah 33,9 \% mengatakan mereka kurang siap karena jaringan internet tidak stabil 
namun ada 28,2\% mahasiswa menjawab siap karena kuota cukup.

Tabel 4.15 Data perangkat yang digunakan saat kuliah daring

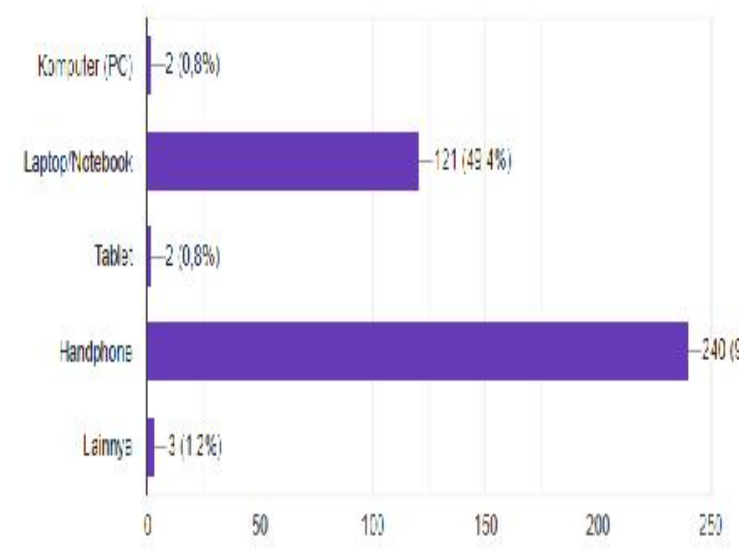

Berdasarkan tabel di atas terlihat bahwa perangkat terbanyak yang digunakan mahasiswa adalah handphone yaitu sebesar $98 \%$.
Berdasarkan tabel di atas disimpulkan bahwa pendapat rata-rata mahasiswa tentang keunggulan kuliah daring adalah pengalaman baru sebesar 68,6\% dan materi terdokumentasi dan dapat dipelajari kembali yaitu sebesar 46,5 \%.

Tabel 4.17 Data kekurangan kuliah daring menurut mahasiswa

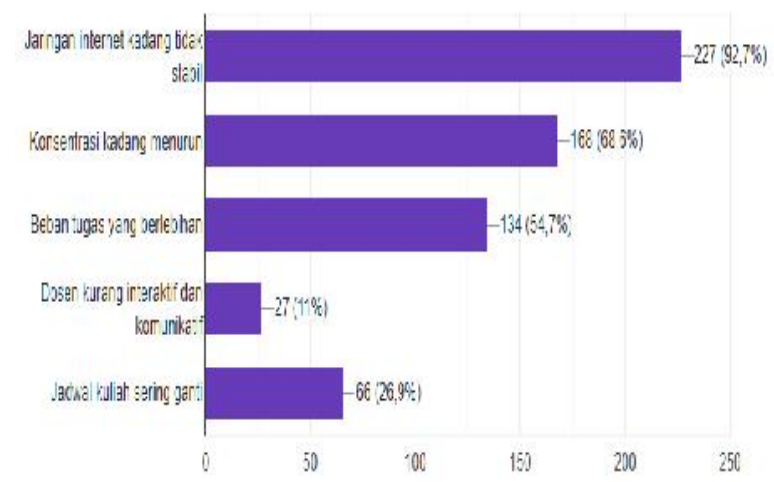

Berdasarkan tabel di atas disimpulkan bahwa pendapat rata rata mahasiswa tentang kekurangan kuliah daring adalah jaringan internet tidak stabil yaitu sebesar $92,7 \%$
Tabel 4.16 Data keunggulan pembelajaran/kuliah daring menurut mahasiswa

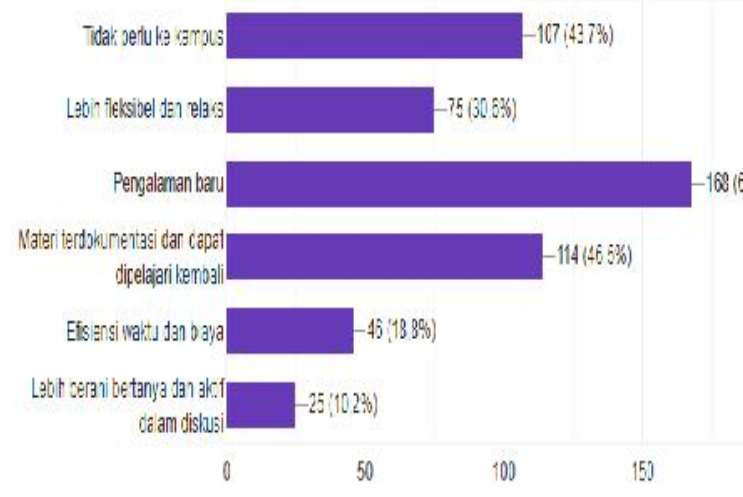

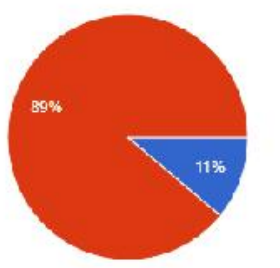

- Pernbe ajaran dering lebin oeik - Pambe ajaran tatap muka Iəoin talk.

Gambar 4.18 perbedaan kuliah daring dan luring

Berdasarkan gambar di atas terlihat sebagian besar mahasiswa mengatakan bahwa pembelajaran tatap muka lebih 
baik dari pembelajaran daring yaitu sebesar $89 \%$.

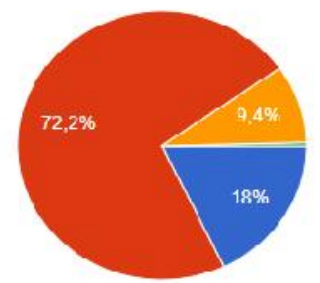

Gambar 4.19 Data materi dan media yang digunakan oleh dosen selama kuliah daring

Berdasarkan gambar di atas terlihat bahwa pendapat mahasiswa tentang materi dan media yang digunakan oleh dosen memuaskan yaitu sebesar 72,2\%.

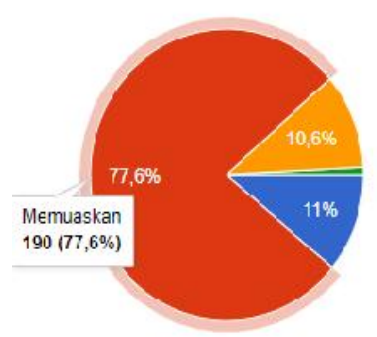

- Sangat memuackar - Memuaskan

Kurang nemuaska

- Tidak menuaskan

Gambar 4.20 .Ketersediaan literatur

Berdasarkan gambar di atas disimpulkan bahwa sebagian besar responden mengatakan ketersediaan literatur untuk kuliah daring memuaskan yaitu sebesar $77,6 \%$
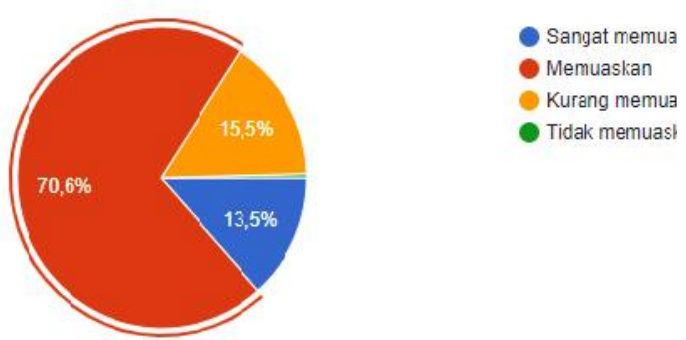

Gambar 4.21 Ketersediaan waktu diskusi antara dosen-mahasiswa

Berdasarkan gambar di atas terlihat sebagian besar responden berpendapat bahwa Ketersediaan waktu diskusi antara dosen-mahasiswa memuaskan yaitu sebesar $70,6 \%$.

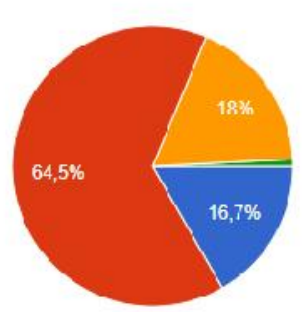

Sangat nemuaskan - Memuaskan

- Kurany memudskan - Tidakmemuaskan

Gambar 4.22 Ketepatan waktu dosen dalam memulai perkuliahan (kedisplinan waktu)

Berdasarkan gambar di atas nampak bahwa sebagian besar responden berpendapat ketepatan dosen memulai perkuliahan memuaskan yaitu sebesar $64,5 \%$.

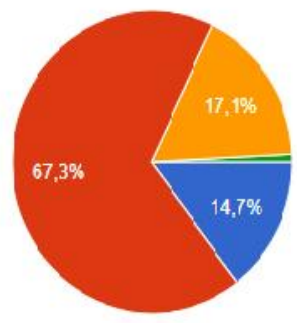

Sangat menuaskan Memuaskan Kurang memuaska?

- Tidak memuaskan

Gambar 4.23 Ketepatan waktu dosen dalam mengakhiri perkuliahan (kedisplinan waktu)

Berdasarkan gambar di atas nampak bahwa sebagian besar responden berpendapat ketepatan dosen mengakhiri perkuliahan memuaskan yaitu sebesar $67,3 \%$.

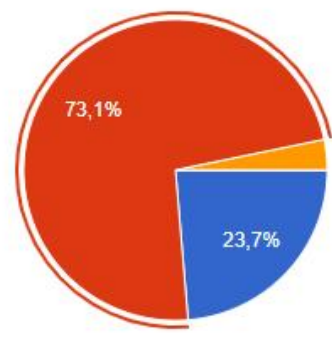

- Sangat memuaskan - Memuaskan Kurang memuaskan - Tidak memuaskan

Gambar 4.24 data Kemampuan/kejelasan dosen dalam menyampaikan rencana perkuliahan, tata tertib dan metode penilaian/evaluasi yang akan dilaksanakan

Berdasarkan gambar di atas disimpulkan 
bahwa sebagian besar responden berpendapat Kemampuan/kejelasan dosen dalam menyampaikan rencana perkuliahan, tata tertib dan metode penilaian/evaluasi yang akan dilaksanakan adalah memuaskan yaitu $73,1 \%$.

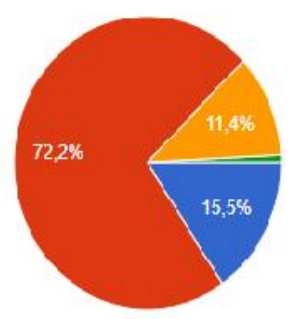

- Sangai memuaskan

- Memuaskan

- Kuranc memuaskan

Tidak memuaskan

Gambar 4.25 Data Pengembalian hasil

koreksi tugas-tugas dan nilai mahasiswa oleh dosen

Berdasarkan gambar di atas terlihat bahwa pendapat responden tentang Pengembalian hasil koreksi tugas-tugas dan nilai mahasiswa oleh dosen adalah sebagian besar memuaskan yaitu 72,2 \%, namun masih ada yang berpendapat kurang memuaskan yaitu 11,4 \%.

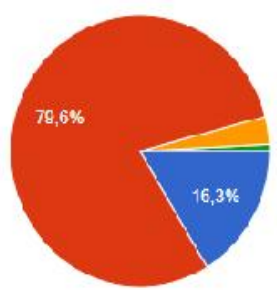

- Saาgal meruaskan - Memuaskan - Kurars memueskan - Tlak memuaskan

Gambar 4.26 Data Jumlah tatap muka dosen dan mahasiswa dalam menyampaikan materi perkuliahan

Berdasarkan gambar diatas disimpulkan bahwa pendapat responden tentang Jumlah tatap muka dosen dan mahasiswa dalam menyampaikan materi perkuliahan adalah sebagian besar memuaskan yaitu sebesar 79,6\% dan sangat memuaskan sebesar $16,3 \%$.

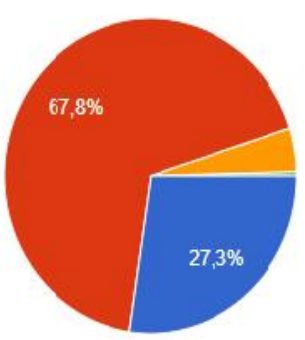

- Sangat memuaskan - Memuaskan Kurang memuaskan - Tidak memuaskan

Gambar 4.27 Data Kecepatan dosen dalam menanggapi atau menjawab pertanyaan mahasiswa

Berdasarkan gambar di atas terlihat bahwa pendapat reaponden tentang Kecepatan dosen dalam menanggapi atau menjawab pertanyaan mahasiswa adalah sebagian besar memuaskan yaitu sebesar $67,8 \%$.

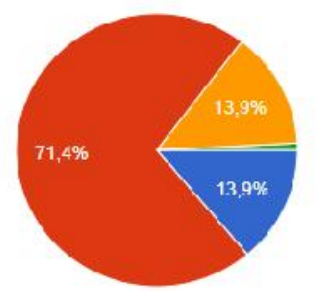

- Sangat memuaska - Memuaskan - Kurang mamulaskan - lıdak memuaskan

Gambar 4.28 Data Kemudahan mahasiswa untuk menghubungi dosen dalam rangka konsultasi/bertanya melalui media daring/online: SMS, telepon, email, whatsApp, line, telegram, dll

Berdasarkan gambar di atas disimpulkan bahwa pendapat responden tentang Kemudahan mahasiswa untuk menghubungi dosen dalam rangka konsultasi/bertanya melalui media daring/online: SMS, telepon, email, whatsApp, line, telegram adalah sebagian besar memuaskan yaitu $71,4 \%$. 


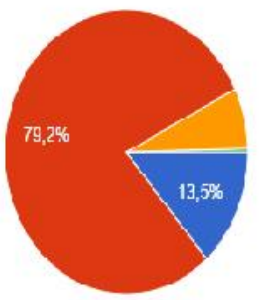

- Sarga: memuaskan

- Merruaskan

- Kurarg merruaskan

- Tidak memuaskan

Gambar 4.29 Kemampuan dosen dalam menggunakan metode/model pembelajaran yang membuat menjadi pembelajaran student center/berfokus pada mahasiswa

Berdasarkan gambar di atas terlihat pendapat responden tentang Kemampuan dosen dalam menggunakanmetode/model pembelajaran yang membuat menjadi pembelajaran student center/berfokus pada mahasiswa adalah sebagian besar memuaskan yaitu 79,2 \%.

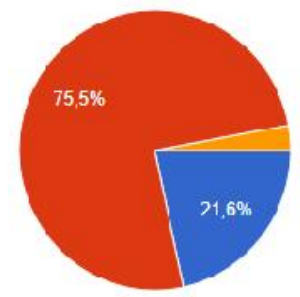

- Sangat mem Jaskan - MernueskanI

Kuranq memuas Can $^{2}$ - Tidak momuacken

Gambar 4.30 Kemampuan/ketrampilan dosen dalam menggunakan media pembelajaran (laptop, HP, vidio, power poin)

Berdasarkan gambar di atas disimpulkan bahwa pendapat responden tentang Kemampuan/ketrampilan dosen dalam menggunakan media pembelajaran (laptop, HP, vidio, power poin) adalah sebagian besar memuaskan yaitu sebesar $75,5 \%$.

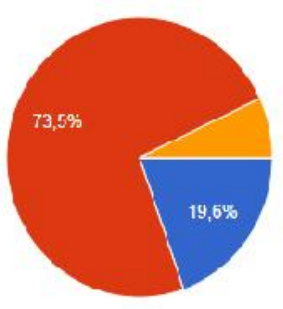

- Sanqat nemuaskan - Memucskan - Kurang memuas can - Tidak memuaskan
Gambar 4.31 Kemampuan dosen dalam menyampaikan materi perkuliahan secara teori/praktikum

Berdasarkan gambar di atas terlihat bahwa pendapat responden tentang Kemampuan dosen dalam menyampaikan materi perkuliahan secara teori/praktikum adalah sebagian besar memuaskan yaitu sebesar $73,5 \%$.

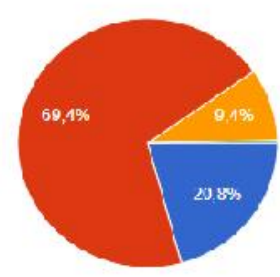

- Sarnjal mituraskan - Memuaskan - Kuranc memuaskan - Titlikk rutrtutskat

Gambar 4.32 Data Kesediaan dosen membantu mahasiswa yang menghadapi masalah di mata kuliah

Berdasarkan gambar di atas disimpulkan bahwa pendapat responden tentang Kesediaan dosen membantu mahasiswa yang menghadapi masalah di mata kuliah adalah sebagian besar memuaskan yaitu sebesar $69,4 \quad \%$ dan $9,4 \quad \%$ kurang memuaskan.
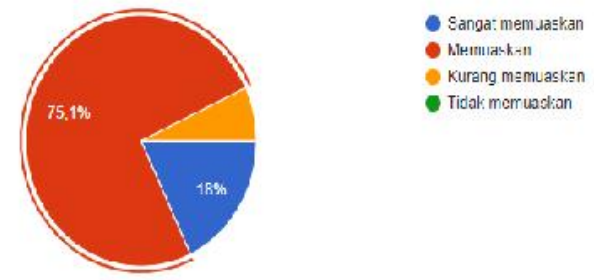

Gambar 4.33 Data Keterbukaan dan sikap kooperatif dosen dengan mahasiswa

Berdasarkan gambar di atas terlihat pendapat responden tentang Keterbukaan dan sikap kooperatif dosen dengan mahasiswa adalah sebagian besar memuaskan yaitu 75,1\%,

\section{PEMBAHASAN}

Sebagian besar mahasiswa mengatakanmereka menggunakan paket internet jenis paket data dan menggunakan handphone untuk mengikuti perkulihan secara daring, sedangkan untuk aplikasi yang digunakan 
terbanyak adalah google class room, zoom dan whatsapp. Sebagian besar mahasiswa mengatakan kurang siap mengikuti kuliah secara daring, hal ini terkait dengan jaringan internet tidak stabil terutama bagi mahasiswa yang daerah tempat tinggalnya sering mengalami gangguan signal karena jangkauan internet yang tidak maksimal dan ketika diberi pilihanmetode pembelajaran yang lebih baik sebagian besar mahasiwa menjawab perkuliahan tatap muka lebih baik dibandingkan dengan kuliah daring.

Model Interaksi pembelajaran, Metode pembelajaran yang digunakan oleh mahasiswa selama proses perkuliahan secara daring.Koneksi internet, Jenis koneksi internet yang dipakai atau dipilih oleh mahasiswa selama mengikuti perkuliahan

daring

Aplikasi pembelajaran, menurut mahasiswa Jenis aplikasi yang digunakan selama proses pembelajaran daring, tingkat pemahaman materi, kemampuan mahasiswa untuk memahami materi perkulaihan yang diberikan oleh dosen secara daring pada umumnya pada tingkat baik atau puas dan sedang, hanya sebagian kecil yang menjawab sangat baik atau sangat puas, hal ini tentu erat hubungannya dengan kemampuan dosen dalam memilih metode dan media serta cara menyampaikan materi ke mahasiswa selama perkuliahan daring

Aspek Tangibles, tingkat kepuasan mahasiswa terhadap sarana pra sarana yang digunakan oleh dosen selama proses pembelajaran daring adalah sebagian besar berpendapat bahwa dosen siap namun masih terdapat beberapa dosen yang dinilai kurang siap oleh mahasiswa.

Aspek Reliability, tingkat kepuasan mahasiswa terhadap pelayanan yang diberikan oleh dosen selama proses pembelajaran daring yang meliputi: kedisplinan, kejelasan menyampaikan materi, bahan ajar dan pemberian nilai/koreksi hasil tugas, sebagian besar mahasiswa berpendapat memuaskan disusul dengan sangat memuaskan, dimana dosen disiplin dalam hal memulai dan mengakhiri jam perkuliahan, jumlah am tatap muka, kemampuan dosen dalam menyampaikan materi, pemberian bahan ajar kepada mahasiswa serta kecepatan dosen dalam mengoreksi dan mengembalikan hasil kerja kepada mahasiswa. Terdapat hal menarik dari apa yang dirasakan oleh mahasiswa selama mengikuti kuliah daring yaitu mengenai perasaan mahasiswa ditemukan hasil sebagian besar mahasiswa menjawab stres lalu disusul dengan perasaan senang dan terdapat sebagian kecil yang menjawab sedih, hal ini dapat dipahami diakibatkan oleh beberapa kendala yang dihadapi antara lain; gangguan signal jaringan internet, mahasiswa kurang memahami materi yang diberikan dan tugas - tugas yang harus dikerjakan terutama untuk materi praktikum.

Aspek emphaty, tingkat kepuasan mahasiswa terhadap pemahaman dosen kepada mahasiswa selama proses pembelajaran daring yang meliputi: kesediaan membantu mahasiswa dengan menjawab pertanyaan, kemudahan dihubungi oleh mahasiswa melalui media sosial, kemampuan menggunakan media pembelajaran, membantu mahasiswa yang sedang bermasalah di mata kuliah serta sikap kooperatif atau terbuka dosen pada umumnya menjawab memuaskan, hanya sebagian kecil yang menjawab kurang memuaskan.

Terdapat beberapa keluhan yangdisampaikan oleh mahasiswa selama mengikuti perkuliahan secara daring yaitu : 1) jaringan internet tidak stabil, kurang fokus dan kurang mengerti apa maksud materi yang disampaikan khususnya untuk praktikum, 2) praktikum online itu 
membuat mahasiswa kurang mengerti apa maksud dari tugas praktikum yang diberikan oleh dosen, 3) tugas banyak dan menumpuk, stres, tugas berlebihan, 4) jaringan yang tidak stabil membuat terkadang lambat untuk masuk perkulihan daring dan terkadang tidak semua dosen bisa memberikan toleransi terhadap masalah tersebut, 5) pembelajaran daring lebih rumit dan membuat suasana menjadi panik karna adanya jaringan yg tidak memuaskan sehinga waktu perkuliahan banyak yg terbuang dan dapat membuat terlambat isi daftar hadir atau pun mengikuti pembelajaran, 6) tenggat waktu untuk pengumpulan tugas yang terlalu cepat, 7) kuliah daring membuat menjadi tidak bersemangat karena susah memahami,Jika ada praktik online yang pertama karena tidak terlalu paham atas apa yg dijelaskan, 8) tidak semua anggota didalam kelompok yg mengerjakan jika tugas kelompok, 9) deadline tugas yang kadang tidak sesuai dengan banyak dan tingkat kesulitan tugas, 10) kesulitan untuk memastikan standar ilmu yang sudah dikuasai sudah sejauh mana dan kesulitan mendapatkan literatur, 11) proses pembelajaran daring yang dilakukan melalui WA atau pesan teks saja kurang efisien, 12) dosen menjelaskan materi ke mahasiswanya kurang interaktif, 13) tidak memiliki teman atau saudara untuk membantu dalam pembuatan video yang sifatnya harus berinteraksi dengan orang lain, berbeda dengan proses praktikum yang dilaksanakan di laboratorium lebih mudah karena ada teman yang juga paham untuk membuat tugas bersama seperti roleplay, 14) merasa kurang bersemangat karena kurang mendapatkan suasana belajar seperti di kampus di sebabkan banyak godaan untuk melakukan kegiatan lain, 15) kesusahan saat mengerjakan tugas kelompok.

Harapan mahasiswa untuk pembelajaran daring antara lain: 1) Tidak ada lagi hambatan jaringan dan semoga kuliah tatap muka bisa cepat berlangsung, 2)
Kuota gratis tetap diberikan, 3) jika ada tugas praktikum online oleh mahasiswa sebaiknya dosen menjelaskan lebih detail bagaimana maksud dan apa yang harus dilakukan untuk tugas yang bapak/ibu dosen yang memberi tugas tersebut agar mahasiswa semua mengerti maksud tugas praktikum online, 3) mohon dosen bisa memaklumi mahasiswa terhadap keadaan jika jaringan yg tidak mendukung, 4)untuk pemberian tugas tidak melebihi batas jam kuliah, 5) dosen dapat memaklumi jika waktu internet terganggu dan lambat isi daftar kehadiran dan mengikuti proses pembelajaran daring, 6) mohon dosen dapat memahami jika ada keterlambatan dalam mengirimkan tugas, karena dalam mengirimkan tugas seringkali mengalami kendala pada jaringan internet, 7)membatasi penggunaan zoom karenajaringan internet yg kurang stabil, 8) Jangan memberikan tugas secara berlebihan dengan waktu yang singkat, gunakan sarana pembelajaran yang mudah diakses oleh semua mahasiswa.

\section{KESIMPULAN}

Proses belajar mengajar secara daring dapat berjalan dengan baik sangat ditentukan oleh hal berikut ini:

\subsubsection{Kampus}

Kesiapan sarana wifi dengan kapasitas yang cukup merupakan hal yang sangat penting agar proses pembelajaran yang dapat berjalan dengan lancar tanpa gangguan signal internet, serta perlu kesiapan ruangan yang kondusif bagi dosen untuk mengajar

\subsubsection{Dosen}

Kesiapan media pembelajaran, pemilihan metode dan aplikasi serta penentuan cara penyampaian materi yang sesuai sangatlah penting agar mahasiswa dapat menerima dan mengerti materi teori dan praktikum yang diberikan dengan baik.

1.1.3 mahasiswa

Pemilihan lokasi tempat tinggal dengan jangkauan signal internetnya baik, tersedianya paket internet; wifi atau 
paket data yang cukup, kesiapan fasilitas laptop atau handphone yang dapat berfungsi dengan baik, persiapan diri agar dapar konsentrasi/fokus untuk mengikuti kuliah misalnya dengan mencari lingkungan atau ruangan yang tenang.

\section{SARAN}

Agar proses pembelajaran secara daring dapat terlaksana dengan baik maka mahasiswa dan dosen harus menyiapkan hal-hal yang mendukung proses pembelajaran, antara lain: 1) kampus menyiapkan jaringan wifi dengan kapasitas yang maksimal, 2) dosen menyiapkan materi, memilih media dan metode yang sesuai 3) mahasiswa harus memilih lokasi tempat tinggal yang jangkauan signal internetnya baik, sediakan paket internet; wifi atau paket data yang cukup, siapkan fasilitas laptop atau handphone, siapkan diri agar dapar konsentrasi/fokus untuk mengikuti kuliah.

\section{DAFTAR PUSTAKA}

Gunawan, H., (2017). Dasar-Dasar Metodologi Penelitian Pendidikan. Bandung: Fakultas Tarbiyah dan Keguruan UIN Sunan Gunung Djati.

Hikmat,dkk, 2020, efektifitas pembelajaran Daring selama Masa

Pandemi Covid-19, UIN Sunan Gunung Djati Bandung.

Jamaluddin, D., Ratnasih, T., Gunawan, H., \& Paujiah, E. (2020). Pembelajaran daring masa pandemik Covid-19 pada calon guru: hambatan, solusi dan proyeksi. LP2M.

Kemendikbud, 2020, pengembangan pembelajaran Daring
Mohamad Toha Anggoro, A.P. Hardhono,Tian Belawati, dan Tri Darmayanti Tutorial Elektronik Melalui Internet Dan Fax-Internet, Jurnal PTJJ-UT, Volume 1.2., (http://www.ut.ic.id)

Sudirman Siahaan; E-Learning (Pembelajaran Elektronik) Sebagai Salah Satu Alternatif Kegiatan Pembelajaran, (http://www.Depdiknas.go.id)

Sugiyono. (2017). Metode Penelitian Kuantitatif, Kualitatif dan $R \& D$. Bandung: Alfabeta. 